\title{
SYSTEMATICS
}

\section{Diversidad y filogenia de Lepanthes en Puerto Rico: ¿especiación o inmigración?}

\author{
Paul Bayman Gupta \\ Departamento de Biología, Universidad de Puerto Rico - Río Piedras, P.O. Box 23360, San Juan, PR 00931-3360; \\ bayman.upr@gmail.com
}

El género Lepanthes tiene cientos de especies, muchas de las cuales tienen distribuciones geográficas muy limitadas. Estas características lo hace un buen modelo para estudiar la diversidad y especiacion de orquídeas. Hay nueve especies de Lepanthes en Puerto Rico, y todas son endémicas. Este trabajo pretende contestar la pregunta: ¿Estas especies son productos de eventos de especiación dentro de Puerto Rico, o representan diversas inmigraciones de otras islas? Para contestarla, se estimaron relaciones filogenéticas entre especies de Lepanthes basadas en secuencias del ADN del cloroplasto. Hubo muy poca variación entre las especies de Puerto Rico, lo cual sugiere que son productos de especiación reciente y no representan múltiples eventos de inmigración.

\section{Development of a novel gene silencing method for orchids}

\author{
R. Frazer ${ }^{1}$, A. Schulte 2 , B. Pomahacova ${ }^{2}$, R. van Vugt ${ }^{3} \&$ B. Gravendeel ${ }^{1 *}$ \\ ${ }^{1}$ NCB Naturalis - NNN Leiden University, Sylviusweg 72, 2333 BE Leiden, The Netherlands \\ ${ }^{2}$ Explant Technologies B.V. \\ ${ }^{3}$ Hortus botanicus - Leiden University \\ *Author for correspondence: barbaragravendeel@ncbnaturalis.nl
}

Orchids contain more than 25,000 species with diverse flowers. Duplications of genes coding for floral shape, color, and symmetry seem to drive this diversity. We are currently developing Erycina pusilla as a model for orchid genomics to find further evidence for this hypothesis. The advantages of this species are that it can easily be grown from seed to flowering stage in less than 6 months and that its genome is small $(1,475 \mathrm{~Gb})$ and currently fully sequenced in Leiden (NCB Naturalis and LGTC) and
China (BGI). Developing Erycina pusilla as a system for functional analysis will add an internationally valued system to the tools currently available for gene silencing of orchids. As a first step we retrieved housekeeping and cell division genes from Illumina HiSeq genome reads for RT PCR and qPCR. Primers for the floral and leaf color genes CHS and PDS were also designed and tested. These will be used in future gene silencing experiments using RNA modulation. 